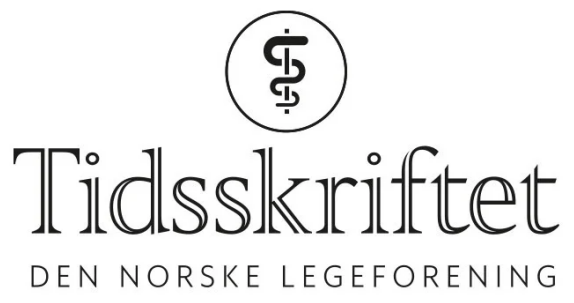

\title{
Blodprøve kan varsle oppbluss av revmatoid artritt
}

FRA ANDRE TIDSSKRIFTER

TORBJ $\varnothing R N \varnothing Y G A R D$ SKODVIN

Tidsskriftet

Forskere har kartlagt molekylære endringer i forkant av sykdomsoppbluss hos pasienter med revmatoid artritt. 


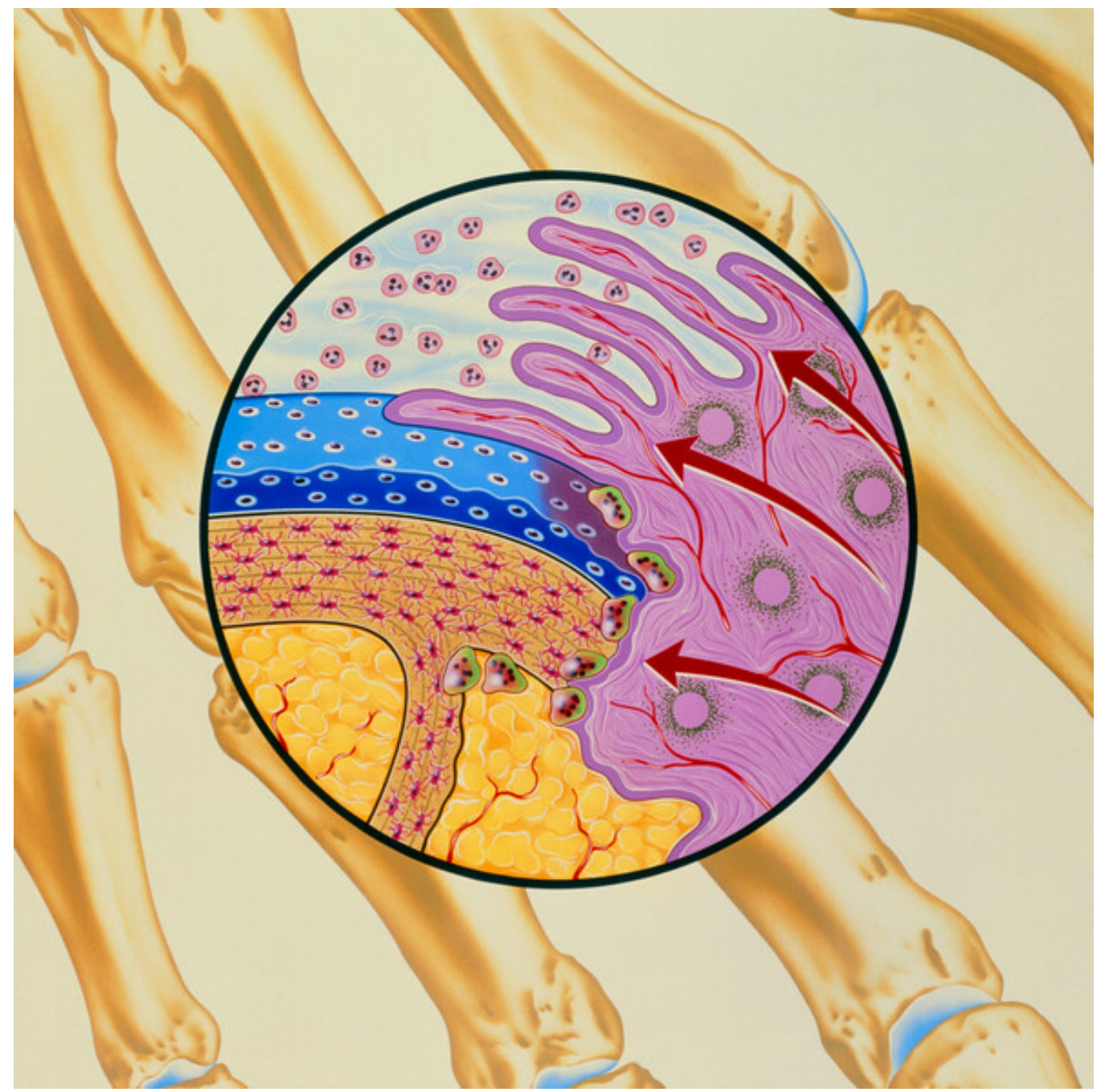

Den betente synovialhinnen produserer fibrøst, vaskulært vev kalt pannus (lilla), som etter hvert vil dekke leddbrusken. Synovialvæsken (hvit) fylles med hvite blodceller som stimulerer frigjøring av enzymer som ødelegger bein og brusk. Illustrasjon: Science photo library / NTB Scanpix

Revmatoid artritt og mange andre inflammatoriske sykdommer karakteriseres av periodiske oppbluss. Vi har begrenset kunnskap om hvilke mekanismer som fører til oppblussene og hvordan de kan forutses.

I en studie som nylig er publisert i New England Journal of Medicine undersøkte forskere fra USA fire pasienter med revmatoid artritt i opptil fire år (1). De fire pasientene tok ukentlige blodprøver hjemme, fylte ut et validert symptomskjema og møtte til månedlige polikliniske konsultasjoner.

1-2 uker før pasientene merket symptomer på sykdomsoppbluss, oppsto endringer i RNAsekvenser i blodet. RNA-sekvensene kjennetegner aktivering av naive B-celler. Aktiveringen ble fulgt av en bølge av en ny celletype som forskerne kalte PRIME-celler. Disse antas å være forløpere til inflammatoriske fibroblaster som slår seg ned i leddenes synovia.

- Et fantastisk spennende arbeid, sier Guro Løvik Goll, overlege og postdoktor ved Revmatologisk avdeling, Diakonhjemmet sykehus. - Metoden med hjemmeprøvetaking av kapillærblod over flere år er en imponerende prestasjon, og jeg vil tro den blir kopiert i fremtidig forskning. Den direkte kliniske nytten ligger lenger frem i tid, men kan ha relevans for andre immunmedierte sykdommer. På sikt kan vi kanskje få en markør for sykdomsaktivitet hos pasienter med f.eks. spondyloartritt eller systemisk lupus erythematosus, sier Goll. 
LITTERATUR

1. Orange DE, Yao V, Sawicka K et al. RNA identification of PRIME cells predicting rheumatoid arthritis flares. N Engl J Med 2020;383: 218-28. [PubMed][CrossRef]

Publisert: 15. september 2020. Tidsskr Nor Legeforen. DOI: 10.4045/tidsskr.20.06o2

(C) Tidsskrift for Den norske legeforening 2023. Lastet ned fra tidsskriftet.no 26. april 2023. 